\title{
FIRST FARMERS IN MAINLAND SOUTHEAST ASIA
}

\author{
Charles F. W. Higham \\ Department of Anthropology and Archaeology, University of Otago, charles.higham@otago.ac.nz
}

\begin{abstract}
The domestication of rice and millet took place in the Yangzi and Yellow River valleys. Current evidence suggests that the expansion of farming communities from these two regions reached mainland Southeast Asia from the late third millennium BC. The conjunction of new archaeological and bioarchaeological information, and the re-examination of older reports, is beginning to illuminate the interactions between the incoming farmers and long-established hunter gatherers. It is argued that there were several distinct expansionary routes. One followed the coast of Vietnam, others involved the courses of the Salween and Mekong rivers. This brought incoming farmers to a wide range of new coastal and inland habitats, and presents the opportunity to examine interactions with indigenous hunter gatherers, and regional patterns of adaptation. Thus Khok Phanom Di is a key site. Formerly located on the estuary of the Bang Pakong River, a new analysis of cranial and dental variables link the inhabitants to expansionary farmers. Their adaptation to a marine estuarine habitat, however, made rice cultivation marginal at best, and the new settlers turned to hunting and gathering while maintaining a fully Neolithic material culture.
\end{abstract}

\section{INTRODUCTION}

Bellwood's synthesis of the global impact of farming generated divisive controversy (Bellwood 2005, 2007, Gamble 2007, Terrell 2007). Mainland Southeast Asia (MSEA) may be seen as a test case to measure the impact of farming over a period measured in millennia, particularly given recent advances in documenting the prehistoric and early historic sequence. While my emphasis is on the archaeological evidence, this must be considered in conjunction with languages, human biology and the environment. I begin at the end of the cultural sequence with the self-evident fact that the civilization of Angkor (c. AD 800-1450) existed on the production of surplus rice. Labour was deployed to divert rivers, fill reservoirs and reticulate water into permanent rice fields (Pottier 2000, Fletcher et al. 2008, Hawken 2011). The texts that survive from the preceding period of Chenla (c. AD 550-880), together with the archaeological evidence for water control, portray competing states in which social divisions involved those who owned rice fields, and their dependents who worked in them. Rice was a medium of exchange, designating wealth (Vickery 1998).

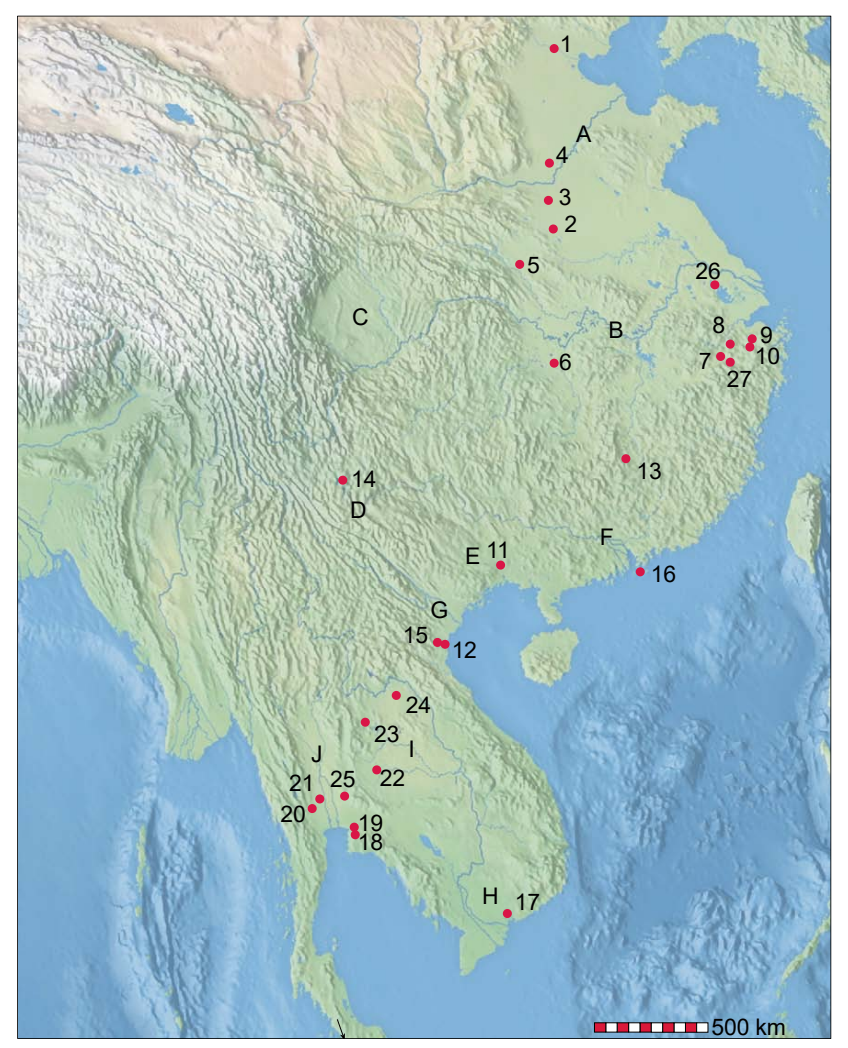

Figure 1: Map of East and Southeast Asia showing sites and locations mentioned in the text. 1. Nanzhuangtou, 2. Jiahu, 3. Peiligang, 4. Cishan, 5. Baligang, 6. Bashidang, 7. Shangshan, 8. Kuahuqiao, 9. Tianluoshan, 10. Hemudu, 11. Dingshishan, 12. Da But, 13. Shixia, 14. Baiyangcun, 15. Man Bac, 16. Sham Wan, 17. An Son, 18. Nong Nor, 19. Khok Phanom Di, 20. Ban Kao, 21. Non Ratchabat, 22. Ban Non Wat, 23. Non Nok Tha, 24. Ban Chiang, 25. Non Pa Wai, 26. Weidun and Songze, 27. Huxi. A. Yellow River, B. Yangzi River, C. Sichuan, D. Yunnan, E. Guangxi, F. Guangdong, G. Red River valley, H. Dong Nai valley, I. Khorat Plateau, J. Central Thailand.

The origins of social inequality have recently been identified in the later Iron Age (c AD 200-600), when increasingly dry conditions stimulated the construction of moat/reservoirs round Iron Age settlements and the adoption of the plough. At this same juncture, we find wealthy elite burials in graves ritually filled with rice (Higham and Thosarat 2007). The presence of wetland weeds strongly suggests cultivation in well-watered fields (Higham 2011, 
Castillo 2014, Wohlfarth et al. 2016). Collectively, these changes have been described as an agricultural revolution (Higham 2014). Rice was a component of the diet during the preceding Bronze Age (c. 1200-500 BC), but cultivation probably relied on natural rainfall. It was during the Neolithic period (c 2200-1200 BC), that rice and millet are first found as domestic crops. Beyond $2200 \mathrm{BC}$, mainland Southeast Asia sustained hunter-gatherers who occupied upland rock shelters, coastal habitats and inland plains. The ancestry of these Anatomically Modern Humans goes back at least 50,000 years, and their descendants survive to this day in the deep forests of the Thai/Malaysian border (Higham 2013).

Identifying when and how domestic rice and millet came to be cultivated in mainland Southeast Asia is thus, surely, a key issue. There are two diametrically opposed models. The first advocates local continuity, in which, "the spread of farming is seen mainly as the result of the adoption and/or diffusion of agricultural technology by the descendants of in situ hunter-gatherers without necessarily the spread of new languages or genes" (Pietrusewsky 2010: 43). This has found support in the distinction between two patterns of tooth morphology, known as Sundadont, and Sinodont (Turner 1990), the former prevalent in Southeast Asia, and the latter concentrating further north. The alternative "two layer" hypothesis advocates the migratory expansion of rice and millet farmers into MSEA from centres of domestication to the north. A somewhat analogous process is seen in the spread of farming via Taiwan into Island Southeast Asia long since advocated by Chang and Goodenough (1985), and subsequently championed by Bellwood.

Whittle and Bickle (2014) have recently stressed the seminal importance of the expansion of Neolithic farmers into Europe in any attempt to understand the later prehistoric period there. This review of the expansion of farming communities into MSEA takes its lead from their reassessment, a study that combined isotopic, genetic, human biological and archaeological analyses. The first essential, is to identify where and when millet and rice were domesticated. Foxtail millet, the only variety so far identified in Southeast Asia, was domesticated in the Yellow River plains, key sites being Nanzhuangtou (Yang et al. 2012), Jiahu, Dadiwan, Peiligang and Cishan (Fig. 1). There was a parallel sequence for rice in the Yangzi River basin seen at Baligang (Deng et al. 2015), Shangshan (10,000-8000 BC), Huxi (7000-6400 BC), and Tianluoshan (Fuller et al. 2009, Zheng et al. 2016). Both stimulated the outward spread of farming communities into the Sichuan Basin and south into Yunnan, Guangxi and Guangdong. Southern China was then occupied by hunter-gatherers, best seen in the Dingshishan culture sites. These are paralleled in northern Vietnam by the Da But culture. Across Southeast Asia in general, there are many upland rock shelter sites, and doubtless many more settlements in drowned Sundaland. These hunter gatherers are often described in the Chinese and Vietnamese literature as Neolithic due to the occurrence of pottery and polished stone adzes. Oxenham and Matsumura (2011: 129) have advocated the term "Pre-Neolithic Pottery using Cultures" to distinguish them from farmers. Almost universally, the former interred the dead in a flexed position with very few, if any, mortuary offerings. Whatever system of nomenclature is preferred, the contrast between them is the basis for the "two layer hypothesis", which involved the intrusion of farmers into a hunter gatherer ecumene, with its implications for human biology, language, gene flows and new cultural configurations. I will now examine new information from a series of important Neolithic settlements.

\section{The Red River Region}

The initial farmer settlement of the strategic Red River plains is represented by the Phung Nguyen culture. Excavations at Man Bac have revealed occupation beginning in about 2000 BC, and a cemetery in which typically Neolithic interment of the dead in a supine position dominated, together with three flexed adult burials. Mortuary offerings included nephrite beads, bracelets and adzes, bone hooks, shell ornaments and up to five pottery vessels (Huffer and Hiep 2011). The pottery vessels recall those found at Sham Wan, Hong Kong, where they have been dated to the late third millennium BC. The inhabitants of Man Bac cultivated rice and raised pigs and dogs. They also hunted deer, cattle and rhinoceros (Sawada et al. 2011) and fished in estuaries, brackish lagoons and along a mangrove shore.

Prima facie a typical intrusive farmer settlement, bioarchaeological research has portrayed a subtler situation. The form and non-metric variables of the crania reveal two groups of individuals, one closely akin to the Neolithic inhabitants of Weidun in the Yangzi Valley and the other to the local hunter gatherers (Dodo 2011, Matsumura 2011a). Metric and non-metric dental traits support the same conclusion. The latter indicate genetic input from the indigenous hunter gatherers, while the former evidence immigration from the north (Matsumura 2011b). mtDNA has been employed to assess biological affinities (Shinoda 2011). Haplogroups D and G are highly represented in East Asian farmer populations, while $\mathrm{F}$ and $\mathrm{B}$ are more likely to be found in Southeast Asian hunter-gatherers. Man Bac burials 1, 5, 9, 10 and 31 have Neolithic East Asian crania, and their haplogroups are DG, DG, F, ND and ND. Burials 27, 30 and 32 have Hoabinhian /Australo-Papuan crania and haplogroups F, F1b and F. As Bellwood (2007) has stressed, recovering skeletal remains opens a direct window on the actual humans, and at this site there are two groups.

\section{The Dong Nai River}

The Dong Nai River in southern Vietnam drains extensive flood plains before entering the South China Sea. The cultural sequence at An Son began with an occupation phase dated between 2300-2000 BC. This very small exposure lacked evidence for rice cultivation or the presence of domestic animals, but a later excavation identified rice phytoliths in the basal layer (Bellwood et al. 2013). The earliest pottery was sand tempered. During the second cultural phase, pottery vessels were decorated with incised patterns and tempered with rice chaff temper (Sarjeant 2012, 2017). 
Neolithic material culture included shouldered and rectangular stone adzes and one-piece barbed fish hooks. The cemetery, dating from 1800 until possibly as late as 1000 $\mathrm{BC}$, contained the graves of adults and infants, laid out in a supine position. Mortuary offerings included pottery vessels, stone adzes and shell beads.

Subsistence after the initial occupation period included rice identified through DNA as Oryza sativa japonica, the variety domesticated in the Yangzi Valley (Bellwood et al. 2011, Castillo 2015). This was associated with the raising of domestic dogs and pigs, the former most abundant and raised for consumption (Piper et al. 2012). Freshwater fish and aquatic turtles were also strongly represented. A superficial glance at the material culture and subsistence at An Son during its second phase suggests intrusive Neolithic settlement by rice farmers. Again, however, it is the bioarchaeology that suggests a more nuanced interpretation. Whereas cranial morphology reveals an intrusive population with northern affinities, the teeth are more akin to the indigenous hunter gatherers.

\section{The Gulf of Siam}

Between 5000-4000 years ago, the period when rice farmers were expanding southward from the Yangzi Valley into southern China, the sea level was higher than at present. The coast, particularly where estuaries and embayments formed, would have provided rich and predictable marine resources. Nong Nor and related sites were located along the shore of a sheltered marine embayment of the Gulf of Siam (Higham and Thosarat 1998: Figure 2). Dating to the $24^{\text {th }}$ century BC, the site comprises a one-phase occupation layer densely packed with marine shellfish that indicate a low energy sandy marine shore, with access to mudflats (Mason 1998). During the occupation, at least one seated and flexed burial was interred. Crabs of the mangal and mudflats were abundant. The inhabitants had easy access to the open sea, and returned bull and tiger sharks and eagle rays to the settlement. Mammalian bones are few, and most were worked or modified. Porpoises were also hunted. No pig or dog bones were identified, and flotation failed to recover a single fragment of rice.

The inhabitants of Nong Nor were proficient potters who created sand-tempered forms decorated by smoothing, cord marking and incised patterns. Stone was a valued import. Just four polished adzes were found, and they had been regularly sharpened with whetstones. Good quality bone was also rare and was converted into barbed fishhooks and awls. Pottery vessels accompanied the single burial encountered, that of an adult female interred in the crouched, seated position typical of hunter gatherers. O'Reilly (1998) has concluded that it was a seasonal base for a community of marine-orientated hunter gatherers, whose ancestral settlements were inundated by the rising sea.

Khok Phanom Di occupies centre stage in any review of the expansion of rice farmers into MSEA. Located 14 $\mathrm{km}$ west of Nong Nor, it commanded the estuary of the Bang Pakong River (Higham and Thosarat 2004). The ini- tial occupation dates to about $2000 \mathrm{BC}$, and over the ensuing five centuries, the sequence is divided into seven mortuary phases and three ceramic periods. Until the recent evaluation of the human remains by Matsumura and Oxenham (2014), this site proved difficult to interpret. Ostensibly a Neolithic occupation site with typically Neolithic burials and ceramics, it was for the greater part of the sequence economically a hunter-gatherer settlement.

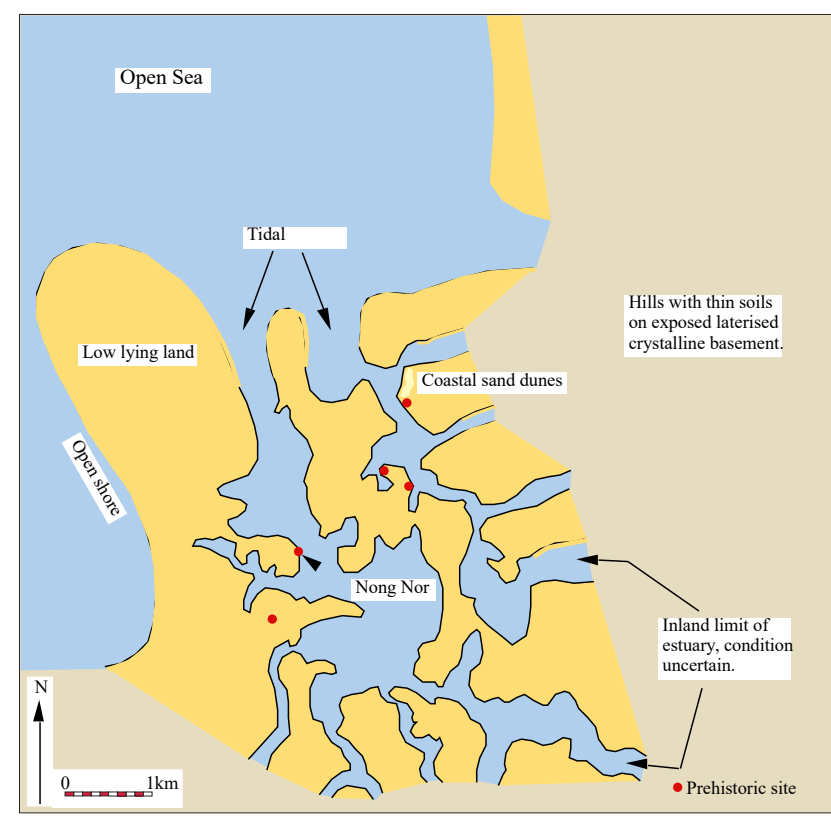

Figure 2: The location of Nong Nor and contemporary hunter gatherer sites relative to the former coastline at $2300 \mathrm{BC}$.

The lowest cultural context comprised ash and charcoal spreads, pits, and shell middens. The forms, temper and decoration of the earliest ceramics match those from Nong Nor. Polished stone adzes, whetstones, awls and the barbed bone fishhooks also parallel those from the earlier site. In her analysis of the seeds and charcoal, Thompson (1996) has reconstructed for this initial settlement phase, a mangrove estuarine habitat backed by salt flats, punctuated by streams flanked by fresh to brackish water swamps. The date, about $2000 \mathrm{BC}$, is a century or so later than the first evidence for the arrival of rice farmers along the coast of Vietnam at Man Bac and An Son, and admixture between the newcomers and hunter gatherers. There are no burials of this initial occupation phase of Khok Phanom Di, but rice husks were present in a cultural context dominated by maritime and estuarine gathering and fishing.

The changing environment over the next five centuries is documented by the recovery of minute shellfish, ostracodes and forams (Mason 1991, McKenzie 1991). The mortuary sequence, prolific artefactual remains and the bioarchaeology of the inhabitants present a rare opportunity to integrate cultural and environmental changes. Burials were superimposed, in discrete clusters, over about 17 generations. There are seven mortuary phases (MP). An estuarine mangrove habitat dominated during MP1-3A. During MP3B-4, the sea level fell and fresh-water swamps formed, 
reverting with MP5-7 to marine conditions. Apart from the brief period of lower sea level, fishing and gathering marine resources, particularly shellfish and crabs, dominated. The few mammal bones included pigs and macaques, both found wild in mangroves. While some pigs might well have been domestic, there is no doubt that the few dogs identified were. There were, however, marked changes in the transition from ceramic period 1 of the initial settlement to the next ceramic phase, when grog replaced sand temper and new forms and decorative patterns were introduced (Figure 3), suggesting to Vincent (2004) the arrival of some new people.

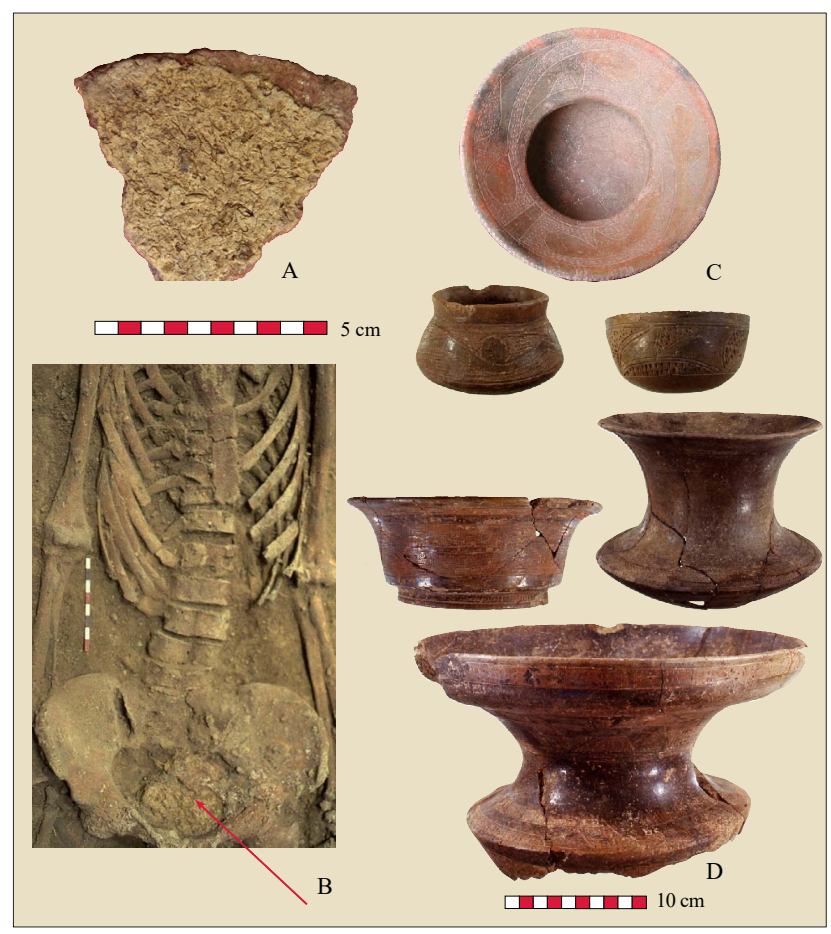

Figure 3: Evidence for rice and Neolithic ceramics from Khok Phanom Di. A. rice impressions on clay found on the surface of a potsherd, B. The stomach contents of a woman, burial 56, that contained rice husks and freshwater fish bones and scales. $C$. Looking into a pottery vessel from burial 11, mortuary phase 6. The incised design is widely paralleled in Southeast Asian Neolithic sites. D. Pottery vessels of with distinct forms but characteristic incised and impressed motifs.

This is reflected in their mortuary tradition. The first graves were cut down into the initial occupation layer, and the dead laid out in a supine position save for one child who was found flexed. There were three adults and the same number of infants and between them, mortuary offerings were just 12 shell beads. Strontium isotopes in the teeth of all three adults identify them as immigrants (Bentley et al. 2007). The ensuing phase saw the establishment of six discrete clusters of inhumation graves that were to accumulate until the end of the MP4. Each contained the graves of men, women and infants. Mortuary offerings included pottery vessels that shone with burnishing, and came in a variety of forms decorated with complex, incised designs typical of the Southeast Asian Neolithic. Shell beads were now common, one man wearing over 39,000.

With MP3B, the sea level fell and fresh water habitats formed. The isotopes in the teeth evidence the arrival of women raised in a different habitat. New pottery forms were placed with the dead. Granite hoes were used, along with shell harvesting knives. Domestic rice was found in the stomach contents of a woman whose carbon isotopes reveal that marine food was only a minor part of her diet (Fig. 3). Domestic rice remains were also found in the faeces recovered from a male grave together with the remains of a beetle and mouse hairs that suggest the presence of rice stores (Thompson 1996). Khok Phanom Di was, at about $1700 \mathrm{BC}$, a rice farming community that traded widely by sea and river.

The sea then rose and marine conditions returned. Shell knives and granite hoes were no longer found. However, the dead of MP5 were now interred with remarkable wealth. A woman potter buried with her anvil, burnishing stones and superb ceramic vessels, wore over 120,000 shell beads, shell discs on her chest, ear ornaments and a bangle. An infant in the adjacent grave wore 12,600 beads, a man of the same period was associated with 57,000 . In the following phase, two wealthy women and a child were buried within a raised, clay-walled building.

Several attempts to recover DNA from the human bones have failed, and the biological affinities of the Khok Phanom Di population have remained enigmatic until a recent analysis of the non-metric dental (Matsumura \& Oxenham 2014) and metric cranial variables (Matsumura et al. 2017). These relate this site closely to Neolithic Weidun and Songze in the Yangzi delta region. Matsumura and Oxenham (2014) have concluded that there was in all probability, a rapid coastal movement by rice farmers to the Gulf of Siam to meet and mix with indigenous hunter-gatherers.

\section{Central Thailand}

Farmer settlements in the interior of Central Thailand fall into two main regions. To the west there are sites grouped under the name Ban Kao, the first site examined (Sørensen and Hatting 1967). East of the Chao Phraya River, settlements concentrate in Lopburi Province. Initial settlement has been dated to at least $2000 \mathrm{BC}$ and possibly a couple of centuries earlier. The dead were interred in an extended, supine position accompanied by ceramic vessels, shell ornaments and stone adzes. The pots were often ornamented with complex incised and impressed designs that reveal a common Southeast Asian Neolithic syntax but with regional variations. Non Pa Wai has yielded domestic millet seeds (Weber et al. 2010); a pottery vessel from a western site was filled with rice husks. Some of the pot designs, and the H-shaped shell beads from Non $\mathrm{Pa}$ Wai, are virtually identical with those from Khok Phanom Di during the $6^{\text {th }}$ mortuary phase. There are also differences in the pottery vessels between the Ban Kao and the Lopburi groups. At the occupation and mortuary site of Non Ratchabat, one finds bowls raised on hollow tripod legs, and remarkable ornamentation in the form of horns and human breasts (Doungsakun 2016). No human remains have yet been 
studied in sufficient detail to comment on their biological affiliations. Sørensen proposed that the ancestry for the Neolithic farmers of Ban Kao lay to the north, in what is now China, with a possible route south along the course of the Salween River. Subsequent excavations, for example at Non Ratchabat, have identified a ceramic tradition, in terms of form and decoration, so distinct from that of the Lopburi region at the same juncture, that a different northern origin might well be the case.

\section{The Khorat Plateau}

The chronological contexts are available for three sites on the Khorat Plateau of Northeast Thailand that evidence early farmer occupation. Initial settlement is consistently later than the coastal sites: Non Nok Tha 1500-1300 BC, Ban Chiang 1600-1450 BC and Ban Non Wat, 1750-1550 BC (Higham et al. 2015). All three share the extended inhumation burial rite, distinct regional ceramic forms but with related incised and impressed decorative elements, and the presence of domestic pigs, cattle, dogs and rice. The cranial morphology links all three sites with the North Asian group that also includes Khok Phanom Di and Man Bac series 1. However, the non-metric dental traits reveal a clinal distribution. While Khok Phanom Di falls into the East Asian farmer group, the Khorat sites retain elements of the indigenous hunter gatherers, suggesting a mixed ancestry.

Some evidence from Ban Non Wat supports this situation. Extended inhumation graves include typical Neolithic incised and impressed pottery, and domestic pig bones. They were contemporary with occupation deposits containing the same ceramics and domestic animal bones, together with fish, shellfish and wild faunal remains. The earliest burials, however, also include individuals found in a flexed position, with quite distinct mortuary offerings. One enigmatic burial contained a male skeleton in a seated, flexed position within a lidded Neolithic pot (Higham and Kijngam 2010). The carbon isotope analysis has singled out three of the flexed individuals as having a diet involving more meat and $\mathrm{C} 4$ plants than the rest, whose isotope signature is compatible with rice consumption (King et al. 2014). Despite close similarities in the cranial morphology between the flexed and extended burials, there is some evidence that initial rice farmers encountered and interacted with indigenous hunter gatherers.

\section{Language and Genes}

There is a network of languages from central India to Vietnam known as Austroasiatic (AA). They are linked by cognate words for rice and many aspects of its cultivation (Higham 2002). Blust (1996) has suggested that AA languages were spread by the expansion of rice farmers into Southeast Asia from the north. There is also some intriguing genetic evidence for a link between prehistoric communities in the southern Khorat Plateau (Figure 1) and AA speakers. Lertrit et al. (2008) have found that mtDNA from Neolithic to Iron Age individuals from the sites of Ban Lum Khao and Noen U-Loke are most closely related to the Chao Bon, a community of nearby Mon (AA) speakers.
Soares et al. (in press) have pinpointed genetic evidence for intrusions into Southeast Asia that probably reflect the expansion of farming groups, followed by an increase in population that would logically include the indigenous hunter gatherers. There is a common genetic ancestry in modern Thai populations that Wangkumhang et al. (2013) identify as probably derived from the spread of AA speaking rice farmers.

\section{DISCUSSION AND CONCLUSIONS.}

Five millennia ago, mainland Southeast Asia was occupied by hunter-gatherers. Contra Gamble (2007) in his dismissal of the Neolithic Revolution as being of little or no consequence, the crystal clear evidence for expansionary movements of rice and millet farmers into the mainland had revolutionary consequences. Perhaps the indigenous hunter gatherers manipulated the landscape to favour yams or some other plants, but social change, while evidenced from about $5000 \mathrm{BC}$, was minimal when compared with the impact of the first rice and millet farmers. Archaeological research has identified cultural changes that took place from about $2200 \mathrm{BC}$ involving people biologically akin to those of the Yangzi and Yellow River valleys to the north. These represent the fifth of eleven demographic thrusts from centres of rice domestication proposed by Fuller et al. (2010). The archaeological signature expressed in burial practices, decoration on ceramic vessels, and presence of domestic rice and millet, pigs and dogs, is so clear, that it is as if one chapter in the prehistory of Southeast Asia opened as its predecessor closed.

Until recent bioarchaeological research became available, I was uncertain how best to interpret the overall sequence of Khok Phanom Di. Now, the study of cranial morphometrics and non-metric dental variations of the inhabitants has shown beyond reasonable doubt that they were incoming rice farmers who interacted with the resident hunter gatherers, and other than during a brief window of opportunity when the sea level fell back, became largely hunter gatherers themselves. Bioarchaeological research has likewise identified mixed populations of indigenous and intrusive groups at An Son, Man Bac and possibly Ban Non Wat.

There was also a striking regionality to the patterns of admixture. In the more remote interior of the Khorat Plateau, the initial settlement by rice farmers was between two and five centuries later than at the coastal sites. Moreover, the biological legacy of the indigenous hunter gatherers, as Matsumura and Oxenham have stressed, was clinal, increasing with distance from the most easily followed coastal or riverine routes. This is seen at its most extreme at the Iron Age site of Phum Snay in Northwest Cambodia, where the human remains are decidedly of Australo-Papuan affinities (Matsumura and Oxenham 2014). This suggests that a missing strand in our understanding of settlement of MSEA includes the adoption of farming by indigenous hunter gatherers.

Further insight into farmer expansion comes from archaeology. Despite an undercurrent of similarity expressed in the mortuary rituals and aspects of the material culture, 


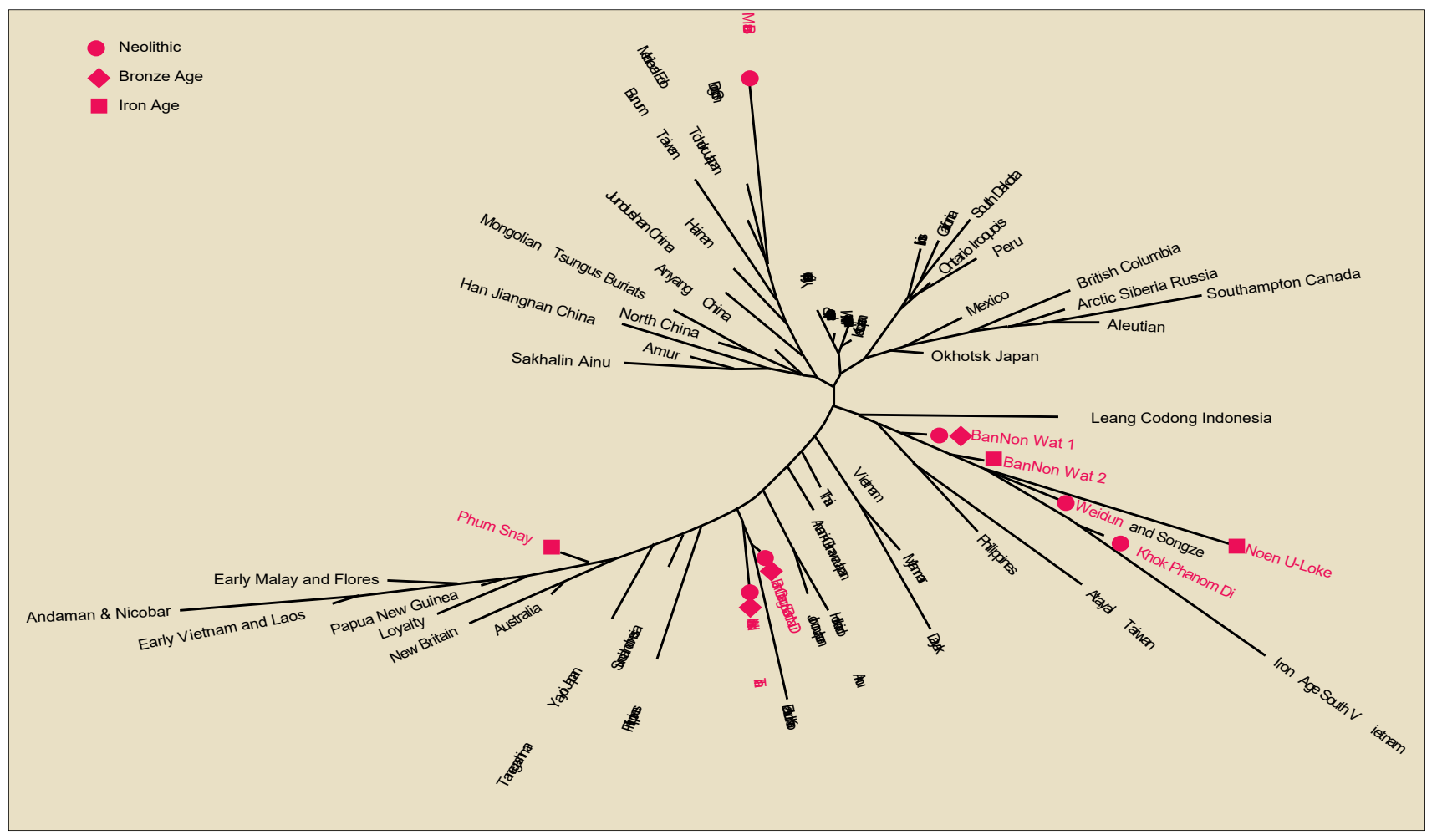

Figure 4. An unrooted neighbour-joining tree analysis applied to the Smith's mean measure of divergence matrix based on a battery of 21 non-metric dental traits. Samples in red are mentioned in the text. Copied from an original by kind permission of Hirofumi Matsumura and Marc Oxenham.

there is also marked regional diversity. There is the Ban Kao group in west-central Thailand, and other distinct groups in the Dong Nai Valley, the Red River flood plains, the Khorat Plateau, the Lopburi region and coast of the Gulf of Siam. It is argued that on present evidence, the Neolithic expansion involved different routes at different times. One may have followed the course of the Salween River, another the coast. The Red and Mekong rivers are also natural corridors for movement.

As the farmer settlement of MSEA clarifies chronologically and culturally, so it becomes necessary to place it in a broader perspective. Thus, intriguing similarities and differences can be identified when compared with the expansion into Europe of LBK farmers, but also significant differences. Distances are similar: 3,000 km separate both Çatalhöyük from the Paris Basin, and the lower Yangzi from the Gulf of Siam. Each involved adaptation to a new environment. In Southeast Asia the putative early farmers encountered much higher temperatures than in the Yellow and Yangzi plains, and a monsoon climate that alternated between wet and dry seasons. In both east and west Eurasia, early farmers moved into lands already occupied by hunter gatherers. Unravelling the patterns of movement and interaction is an essential challenge to the prehistorian, and in due course, will encourage comparisons between the two regions.

In MSEA, new bioarchaeological research has emphasized the genetic contribution of indigenous hunter gatherers to early farming communities. As Szécsényi-Nagy et al.
(2014) have shown however, LBK individuals present homogenous and exotic mtDNA with barely any reflection of hunter-gatherer relationships. There is virtually no evidence for skeletal trauma in Neolithic Southeast Asia that might indicate inter-group violence. However, as seen at Talheim, all evidence points to the slaughter of one LBK community by another. This was not isolated: murder of young and old is also seen at Wiederstedt and SchöneckKilianstädten (Meyer et al. 2014). The incoming farmers in Southeast Asia adapted to a variable series of habitats. For those following a coastal route, the salinity of marine habitats made rice cultivation marginal at best. The farmer settlers at Khok Phanom Di faced this problem, and reverted to hunting and gathering. In the interior plains, rice cultivation and pig and cattle husbandry were part of an economy that incorporated hunting, fishing and collecting. Communities were networked through exchange in exotic items, such as cowries, marine shell ornaments and ceramics. Whittle and Bickle (2014:1) have written that "The Neolithic period worldwide can readily be identified as one of the great transformations in human history". I conclude that in MSEA the Neolithic was brief but seminal. Barely a millennium after its inception, knowledge of bronze production and consumption spread rapidly from its immediate source in southern China, along established exchange links. A thousand years later still, a sharp climatic deterioration stimulated an agricultural revolution in rice production that led directly to the foundation of early states. 


\section{ACKNOWLEDGEMENTS}

I acknowledge the permission given me by the Thai National Research Council and Fine Arts Department, that allowed me to undertake fieldwork Funding came from the University of Otago, the Ford Foundation, the Marsden Fund of New Zealand and Earthwatch and its Research Corps. I acknowledge most insightful comments by Peter Bellwood and Marc Oxenham, the assistance given me by Hirofumi Matsumura, and the contribution of my co-directors Rachanie Thosarat and Amphan Kijngam.

\section{REFERENCES}

Bellwood, P.2005. First Farmers: the Origins of Agricultural Societies. Oxford: Blackwell.

Bellwood, P.2007. Overview. Cambridge Archaeological Journal 17: 88-91.

Bellwood, P., M. Oxenham, B.C. Hoang, N.T.K. Dung, A. Willis, C. Sarjeant, P.J. Piper, H. Matsumura, K. Tanaka, N. Beavan, T. Higham, N. Q. Manh, D.N. Kinh, N. Khanh, T. Kien, V.T. Huong, V.N. Bich, T.T.K. Quy, N.P. Thao, F. Campos, Y-I. Sato, N.L. Cuong \& N. Amano 2013. An Son and the Neolithic of Southern Vietnam. Asian Perspectives 50:144-75.

Bentley, A., N. Tayles, C.F.W. Higham, C.Macpherson \& T.C. Atkinson 2007. Shifting gender relations at Khok Phanom Di, Thailand: Isotopic evidence from the skeletons. Current Anthropology 48(2): 301-14.

Blust, R. 1996. Beyond the Austronesian homeland: the Austric hypothesis and its implications for archaeology, in W.H. Goodenough (ed.) Prehistoric Settlement of the Pacific. Transactions of the American Philosophical Society 86: 117-40.

Castillo, C.C. 2014. The Botanical Remains. In Higham et al. The Excavation of Non Ban Jak, Northeast Thailand. The first three seasons. Journal of Indo-Pacific Archaeology 34: 379.

Castillo, C.C., K. Tanaka, Y.-I. Sato, R. Ishikawa, B. Bellina, B., C.F.W. Higham, N. Chang, N., R. Mohanty, M. Kajale and D.Q. Fuller 2015. Archaeogenetic study of prehistoric rice remains from Thailand and India: evidence of early japonica in South and Southeast Asia. Archaeological and Anthropological Science DOI 10.1007/s12520-015-0236-5

Chang, K.C. and W. Goodenough 1985. Archaeology of southern China and its bearing on the Austronesian homeland. in W.H. Goodenough (ed.) Prehistoric Settlement of the Pacific. Transactions of the American Philosophical Society 86: 36-56.

Deng, Z., L. Qin, Y. Gao, A.R. Weisskopf, C. Zhang and D.Q. Fuller 2015. From early domesticated rice of the Middle Yangtze Basin to millet, rice and wheat agriculture: archaeobotanical macro-remains from Baligang, Nanyang Basin, Central China $(6700-500 \quad$ BC). Plos One 10(10):e0139885.doi:10.1371/journal.pone.0139885.

Dodo, Y. 2011. Qualitative cranio-morphology at Man Bac, M. Oxenham, H. Matsumura and D.K. Nguyen (eds.),Man Bac. The Excavation of a Neolithic Site in Northern Vietnam. The Biology.Terra Australis 33:33-42.

Doungsakun, S., 2016. Recent research on the Ban Kao Culture, Western Thailand. Paper read at the 50th anniversary of the discovery of Ban Chiang meeting, Udorn Thani, Thailand.
Fletcher, R., Pottier, C., Evans, D. and Kummu, M. 2008. The development of the water management system of Angkor: a provisional model. BIPPA 28: 57-66.

Fuller, D.Q., L Qin, Y. Zheng, Z. Zhao, X. Chen, L.A. Hosoya and G.P. Sun 2009. The domestication process and domestication rate in rice: spikelet bases from the Lower Yangtze. Science 323: 1607-10.

Fuller, D. Q., I. Sato, C.C. Castillo, L. Qin, A.R. Weisskopf, E.J. Kingwell-Banham, J. Song, S-M Ahn, and J. van Etten2010. Consilience of genetics and archaeobotany in the entagled history of rice. Archaeological and Anthropological Science 2: 115-31

Gamble, C. 2007. No Neolithic Revolution. Cambridge Archaeological Journal 17: 91-3.

Hawken, S. 2011. Metropolis of Ricefields: a Topographic Classification of a Dispersed Urban Complex. Unpublished Ph.D thesis, University of Sydney.

Higham, C.F.W. 2002. Languages and farming dispersals: Austroasiatic languages and rice cultivation, in P. Bellwood and C. Renfrew (eds.), Examining the Farming/Language Dispersal Hypothesis. Cambridge, McDonald Institute, 223-32.

Higham, C.F.W. 2011. The Iron Age of the Mun Valley, Thailand. The Antiquaries Journal 91:1-44.

Higham, C.F.W. 2013. Hunter-Gatherers in Southeast Asia: From Prehistory to the Present. Human Biology 85:21-44.

Higham, C.F.W. 2014 From the Iron Age to Angkor: new light on the origins of a state. Antiquity 88: 822-35.

Higham, C.F.W., K. Douka and T.F.G. Higham 2015. A new chronology for the Bronze Age of Northeastern Thailand and its implications for Southeast Asian Prehistory. Plos One

http://journals.plos.org/plosone/article?id=10.1371/journal.pone.0137542

Higham, C.F.W. and A. Kijngam, (eds.) 2010. The Origins of the Civilization of Angkor.Volume IV. The Excavation Ban Non Wat: the Neolithic Occupation. Bangkok: The Fine Arts Department of Thailand.

Higham, C.F.W. and R. Thosarat,(eds.) 1998. The Excavation of Nong Nor, a Prehistoric Site in Central Thailand. Oxford: Oxbow Books and University of Otago Studies in Prehistoric Anthropology no. 18.

Higham, C.F.W. and R. Thosarat 2004. The Excavation of Khok Phanom Di: Volume VII. Summary and Conclusions. London: The Society of Antiquaries of London.

Higham, C.F.W. and R. Thosarat 2007. The burials of mortuary phase 3 cluster B, in C.F.W. Higham and A. Kijngam and S. Talbot (eds.) The Excavation of Noen U-Loke and Non Muang Kao. Bangkok, the Fine Arts Department: 159-71.

Huffer, D.G. and T.H. Hiep 2011. Man Bac burial descriptions, in M. Oxenham, H. Matsumura and Nguyen, D.K. (eds.) Man Bac. The Excavation of a Neolithic Site in Northern Vietnam. The Biology. Terra Australis 33:135-168.

King, C.I., R.A. Bentley, C.F.W. Higham, N.G. Tayles, U.S. Viðarsdóttir, R. Layton, C.G. MacPherson and G. Nowell 2014. Economic change after the agricultural revolution in Southeast Asia? Antiquity 88: 112-25.

Lertrit, P., S. Poolsuwan, R. Thosarat R., T. Sanpachudayan, H. Boonyarit C. Chinpaisal \& B. Suktitipat 2008. Genetic history of prehistoric Asian populations as revealed by ancient 
and modern mitochondrial DNA analysis. American Journal of Physical Anthropology 137(4): 425-40.

Mason, G.M. 1991. The molluscan remains, in C.F.W. Higham and R. Bannanurag (eds.) The Excavation of Khok Phanom Di Volume II. The Biological Remains (Part I): 259-319. Research Reports of the Society of Antiquaries of London No. XLVIII. London: Society of Antiquaries.

Mason, G.M. 1998. The shellfish, crab and fish remains, in C.F.W. Higham and R. Thosarat (eds.) Nong Nor. A Prehistoric Site in Central Thailand: 173-211. Oxford: Oxbow Books and University of Otago Studies in Prehistoric Anthropology no. 18.

Matsumura, H. 2011a. Quantitative cranio-morphology at Man Bac, in M. Oxenham, H. Matsumura and D.K. Nguyen (eds.) Man Bac. The excavation of a Neolithic Site in Northern Vietnam. The Biology. Terra Australis 33:21-32.

Matsumura, H.2011b. Quantitative and qualitative dental morphology at Man Bac, in M. Oxenham, H. Matsumura and D.K. Nguyen (eds.) Man Bac. The Excavation of a Neolithic Site in Northern Vietnam. The Biology. Terra Australis 33:43-63.

Matsumura, H. and M. Oxenham 2014. Demographic transitions and migration in prehistoric East/Southeast Asia through the lens of nonmetric dental traits. American Journal of Physical Anthropology 155:45-65.

Matsumura M, Oxenham M, Simanjuntak T, Yamagata M. 2017. The biological history of Southeast Asian populations from Late Pleistocene and Holocene cemetery data. In P Bellwood. First Islanders: Prehistory and Human Migration in Island Southeast Asia. Oxford: Wiley Blackwell, p. 98106.

McKenzie, K.G. 1991. The Ostracodes and Forams. In Higham, C.F.W. and R. Bannanurag (eds.), The Excavation of Khok Phanom Di.Volume 2 (part 1): The Biological Remains, pp. 139-46. London: Society of Antiquaries of London, Research Report no. XLVIII.

Meyer, C., Lohr, C., O. Kürbis, Y. Veit Dresely, W. Haak, C.J. Adler, D. Gronenborn\& K.W. Alt 2014. Mass graves of the LBK: patterns and peculiarities, in A. Whittle and P. Bickle (eds.) Early Farmers. The View from Archaeology and Science: 307-27. London: the British Academy.

O’Reilly, D.J.W. 1998. Nong Nor phase one in a regional context, in C.F.W. Higham and R. Thosarat (eds.) The Excavation of Nong Nor, a Prehistoric Site in Central Thailand, pp. 509-522. Oxbow Books, Oxford and University of Otago Studies in Prehistoric Anthropology no. 18.

Oxenham, M. and H. Matsumura 2011. Man Bac: regional, cultural and temporal context, in M. Oxenham, H. Matsumura and D.K. Nguyen (eds.) Man Bac. The Excavation of a Neolithic Site in Northern Vietnam. The Biology, pp. 12733.Terra Australis 33.

Pottier, C. 2000. Some evidence of an inter-relationship between hydraulic features and rice field patterns during ancient times. The Journal of Sophia Asian Studies 18: 99-119.

Pietrusewsky, M. 2010. A multivariate analysis of measurements recorded in early and more modern crania from East Asia and Southeast Asia. Quaternary International 211: 42-54.

Piper, P., Campos, F., Kinh, D.N., Amano, N., Oxenham, M., Hoang, B.C., Bellwood, P. and. Willis, A. 2012. Early evidence for pig and dog husbandry from the Neolithic site of An Son, Southern Vietnam. International Journal of Osteoarchaeology DOI: 10.1002/oa2226.
Sarjeant, C. 2012. The role of potters at Neolithic An Sơn, southernVietnam. Unpublished $\mathrm{PhD}$ thesis, Australian National University.

Sarjeant, C. 2017. An Son Ceramics in the Neolithic Landscape of Mainland Southeast Asia. In P.J. Piper, H. Matsumura and D. Bulbeck, D. (eds.) New Perspectives in Southeast Asian and Pacific Prehistory, Terra Australis 45:165-188

Sawada, J., N.K. Thuy and N.K. Tuan 2011. Faunal remains at Man Bac, in M. Oxenham, H. Matsumura and D.K. Nguyen (eds.) Man Bac. The Excavation of a Neolithic Site in Northern Vietnam. The Biology pp. 105-116. Terra Australis 33 .

Shinoda, K. 2011. Mitochondrial DNA of human remains at Man Bac, in M. Oxenham, H. Matsumura and D.K. Nguyen (eds.) Man Bac. The Excavation of a Neolithic Site in Northern Vietnam. The Biology, pp. 95-116. Terra Australis 33 .

Soares, P., M. Mormina, T. Rito and M.B. Richards in press. The archaeogenetics of Southeast Asia, in C.F.W. Higham and N. Kim (eds.) The Oxford Handbook of Southeast Asian Prehistory. Oxford: Oxford University Press.

Sørensen, P. and T. Hatting 1967. Archaeological Investigations in Thailand.Volume II, Ban Kao, Part 1: The Archaeological Materials from the Burials. Copenhagen: Munksgaard.

Szécsényi-Nagy A., V. Keerl, J. Jakucs, G. Brandt, E. Bánffy and K.W. Alt 2014. Ancient DNA evidence for a homogeneous maternal gene pool in sixth millennium cal BC Hungary and the Central European LBK, in A. Whittle and P. Bickle (ed.) Early Farmers. The View from Archaeology and Science, pp. 71-93. London: the British Academy.

Terrell, J.E. 2007. The Rudiments of Agriculture and Domestication. Cambridge Archaeological Journal 17: 100-102.

Thompson, G.B. 1996. The Excavation of Khok Phanom Di. A Prehistoric Site in Central Thailand. Volume IV. Subsistence and Environment: the Botanical Evidence (The Biological Remains, Part II). London: Society of Antiquaries of London Research Report LIII.

Turner, C.G. 1990. 1990. Major Features of Sundadonty and Sinodonty, Including Suggestions About East Asian Microevolution, Population History, and Late Pleistocene Relationships With Australian Aboriginals. American Journal of Physical Anthropology 82:245-317.

Vickery, M. 1998. Society, Economics and Politics in Pre-Angkor Cambodia. Tokyo: The Centre for East Asian Cultural Studies for Unesco.

Vincent, B.A. 2004. Khok Phanom Di: The Pottery. London: Research Report of the Society of Antiquaries of London LXX.

Wangkumhang, P., P.J. Shaw, K. Chaichoompu, C. Ngamphiw, A. Assawamakin, M., Nuinoon, O. Sirpichai and Svasti, S. 2013.Insight into the Peopling of Mainland Southeast Asia from Thai Population Genetic Structure. http://dx.doi.org/10.1371/journal.pone.0079522

Weber, S., H. Lehman, T. Barela, S. Hawks and D. Harriman 2010. Rice or millets? Early farming strategies in prehistoric central Thailand. Anthropological and Archaeological Science 2: 79-88.

Whittle, A. and P. Bickle, (eds.) 2014. Introduction. Integrated and multi-scalar approaches to early famers in Europe, in A. Whittle and P. Bickle (eds.) Early Farmers. The View from Archaeology and Science, pp. 1-19. London: the British Academy. 
Wohlfarth, B., Higham, C.F.W., Yamoah, K.A., Chabangborn, A, Chawchai, S. and Smittenberg, R.H. 2016. Human adaptation to mid- to late-Holocene climate change in Northeast Thailand. The Holocene 26(4): 614-26.

Yang, X., Z. Wan, L. Perry, H. Lu, Q. Wang, C. Zhao, J. Li, F. Xie, J. Yu, T. Cui, T. Wang, M. Li \& Q. Ge 2012. Early millet use in northern China. Proceedings of the National Academy of Sciences 109: 3726-30.

Zheng Y., Crawford, G.W., Jiang, L. and Chen, X. 2016. Rice domestication revealed by reduced shattering of archaeological rice from the lower Yangtze Valley. Scientific Reports 6, Article number: 28136, | 6:28136 | DOI: 10.1038/srep28136. 